\title{
Analysis of Different Stripe Connectors for a Gabion Wall based on Woven Waste Tire Stripes
}

\author{
Apriyono, A. ${ }^{*}$, Sumiyanto ${ }^{1}$, Yanto ${ }^{1}$, Iswahyudi, S. ${ }^{1}$, and Pamungkas, R.W. ${ }^{1}$
}

\begin{abstract}
In this research, woven waste tire stripes are proposed as an alternative material to wire mesh to make a gabion wall. The performance of the waste tire stripe-based gabion wall is highly dependent on the strength of its stripe, where the stripe connector plays an important role. This research aims to inspect the behavior of different stripe connectors for the gabion wall. To achieve this, a physical model was built and employed to test the strength of the gabion wall. Various stripe connectors are used; adhesive rubber glue, one inch nail, and two mm wire. The strength capacity of the models was determined from the maximum stress before failure. The strength capacities of the models are $83.197,59.426$ and $62.397 \mathrm{kPa}$ for the wire, nail, and glue connector, respectively. Hence, it can be inferred that the wire connector is the strongest of the three connectors.
\end{abstract}

Keywords: Woven waste tire stripe; gabion wall; connector type.

\section{Introduction}

There have been 4,799 landslide events recorded in Indonesia, causing more than 2,000 fatalities and 200,000 refugees since 2009 [1]. As shown in Figure 1 , the number of landslide occurrences has increased in the last decade. Since early warning systems have not been installed in most landslide areas and many of the installed early warning systems have not worked properly, prevention and mitigation efforts are critical.

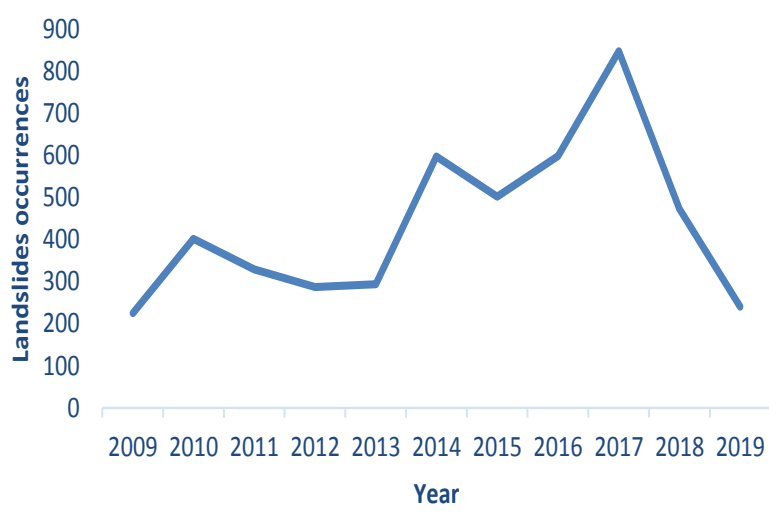

Figure 1. Landslide Occurrences in Indonesia since 2009 [1].

\footnotetext{
${ }^{1}$ Civil Engineering Department, Jenderal Soedirman University, Purwokerto, INDONESIA

${ }^{*}$ Corresponding author: apif.miptahul.ft@um.ac.id
}

Note: Discussion is expected before November, $1^{\text {st }} 2019$, and will be published in the "Civil Engineering Dimension", volume 22, number 1, March 2020.

Received 09 Jyly 2019; revised 11 July 2019; accepted 22 July 2019.
Among the several causes of landslides, rainfall is the most common phenomenon that triggers landslides. Infiltration, the process by which rainfall enters the soil, reduces the shear strength of soil and increases its weight, thereby reducing its soil stability. When infiltration occurs near a stream bank area, together with the erosion caused by the increasing stream flow, this triggers a riverbank landslide. In fact, many landslides in Indonesia are induced by erosion, especially around riverbank areas $[2,3]$. Hence, prevention and mitigation measures for riverbank landslides are important. Gabion walls are used to prevent landslides triggered by erosion.

Gabion walls, consisting of a retaining structure commonly made from galvanized steel wire mesh filled with stone, are a widely-used structure to prevent erosion in riverbank areas. With respect to economic considerations, we propose woven waste tire stripes as an alternative material instead of wire mesh. If the budget to make gabion walls can be reduced, landslide mitigation can be applied more effectively.

Made from woven waste tire stripes web, the performance of the mesh is highly dependent on the strength of its stripe, where the stripe connector plays an important role. This research aims to inspect the behavior of different stripe connectors of a woven waste tire strips gabion wall. The most efficient stripe connector types used for waste tire stripes gabion walls are analyzed.

\section{Gabion Walls}

Gabion walls are the most common structure to prevent riverbank landslides. Galvanized steel wire mesh is widely used to build gabion wall frameworks 
so that rocks can be filled into them. They are stacked one above the other and securely tied together to form a massive structure. An example of a conventional gabion wall structure is presented in Figure 2 $[2]$.

As can be seen from Figure 2, the galvanized steel wire mesh is crafted by twisting the longitudinal and transversal axes of the wire. Hence, the strength of the mesh is dependent on the wire strength and its connection. While the construction of a galvanized steel wire mesh is simple, its mass production requires significant financial resources. Therefore, its application for many landslide locations is limited due to a lack of financial resources within local government and communities. Therefore, an alternative material to build gabion wall meshes would be invaluable.

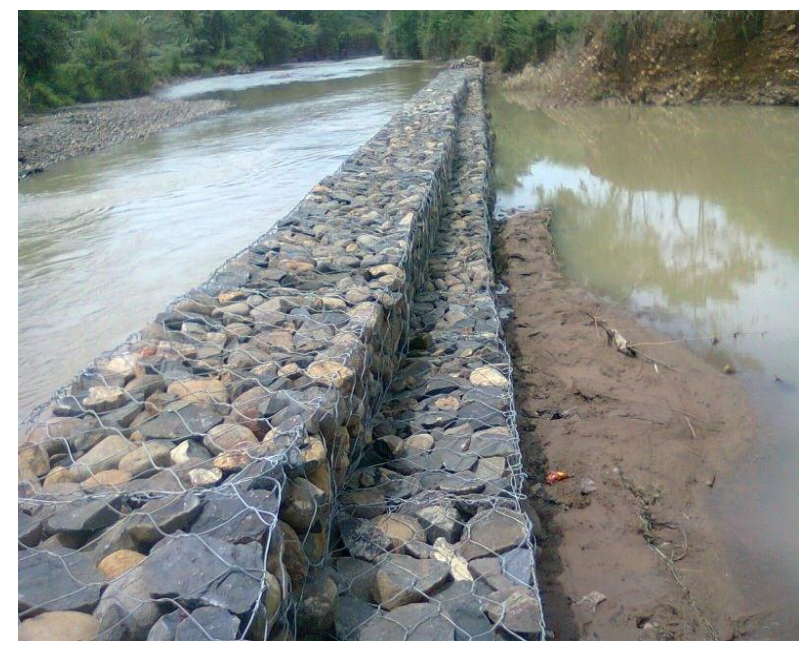

Figure 2. Conventional Gabion Wall [3].

\section{Woven Waste Tire Gabion Wall}

According to early research, there are many structures in civil engineering that use waste tires. Using waste tires in our structures could improve their quality, as well as helping to solve environmental problems.

Waste tires are usually mixed with basic construction materials, such as concrete Singh and Singh [4] and Bjegovic et al. [5] reported that waste tires can improve the mechanical and durability of concrete. In pavement structures, this material increases its flexural strength and toughness [6,7]. In geotechnical engineering, waste has been used in several cases, such as soft soil stabilization [8], back fill reinforcement [9], and scouring prevention [10].

The application of waste tires in gabion walls was studied by Apriyono et al. [11] analyzing the correlation between gabion wall strength and the stripe distance-boulder diameter ratio. In that study, a glue connector was applied on each stripe with a 3 $\mathrm{cm}$ width and a $2 \mathrm{~mm}$ thickness. The gabion model is shown in Figure 3. The result suggests that a stripe distance-boulder diameter ratio of 0.4 is optimum with a corresponding strength value of $1,718 \mathrm{~kg}$.

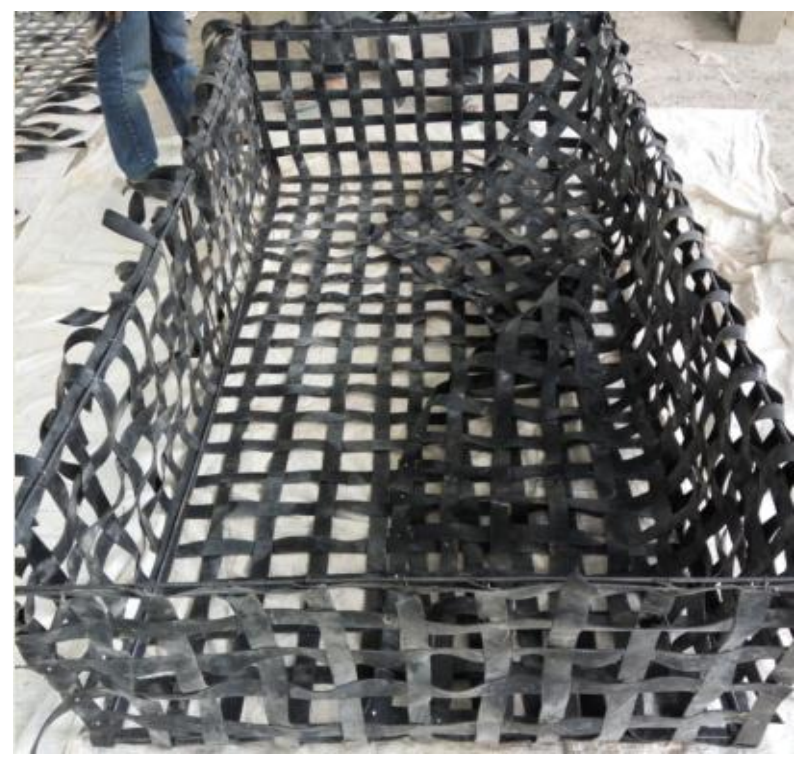

Figure 3. Gabion Wall Model Based on Woven Waste Tire Stripes [11].

\section{Method}

As described in the previous section, the strength of a gabion wall mesh is highly dependent on the strength of its connection. Three potential connectors to connect the stripes, namely, glue, nail, and wire are considered. The most efficient stripe connector for the waste tire stripe gabion wall is sought in this study. To achieve this, laboratory half-scale model testing was conducted, as described below.

\section{Experimental Models}

The gabion wall was made from web that was arranged using waste tire stripes. Each stripe was 3 $\mathrm{cm}$ in width and at least $2 \mathrm{~m}$ in length. To create the firm web, the joint between the transverse and longitudinal directions stripes has to be connected tightly. Three connectors were used in this study, as shown in Figure 4.

The most effective connector is measured by conducting a loading test to the three variations. Therefore, half-scale gabion wall models, each sized $50 \mathrm{~cm}$ $\times 50 \mathrm{~cm} \times 25 \mathrm{~cm}$, were made. To reinforce the gabion wall structure, a $4 \mathrm{~mm}$ diameter steel bar frame is used as long as this structure, so it could stand by itself. A single model for every variation of stripe connector was loaded to determine the maximum strength of gabion wall. An example gabion wall model is shown in Figure 5. 


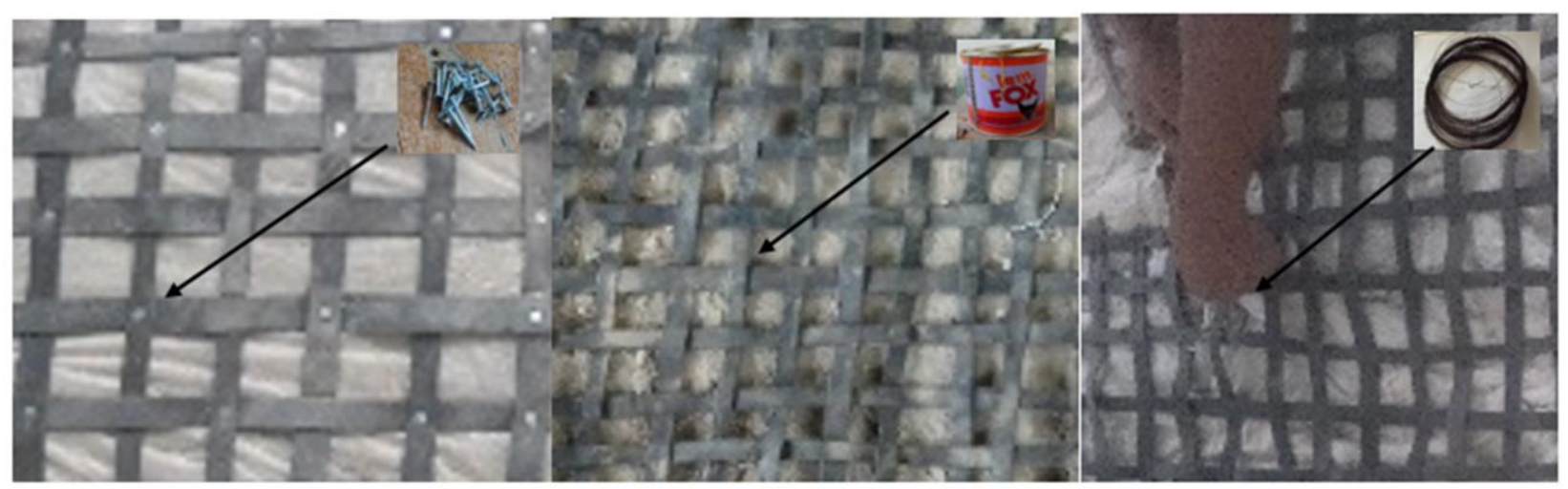

Figure 4. Types of Connector used in this Study.

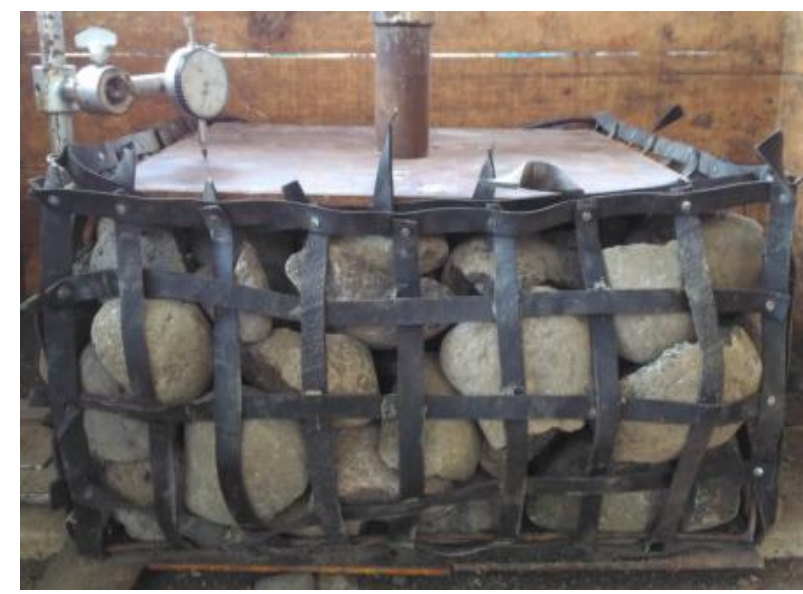

Figure 5. Gabion Wall Model Connected by Nails.

\section{Loading Test}

To achieve this experimental study, a loading test framework made from $\mathrm{H}$-profile steel was prepared (see Figure 6). Every tool that was required in this test i.e., the loading tool, load dial, and dial gauge, were set up in this framework. The loading test framework and set-up is shown in Figure 6.

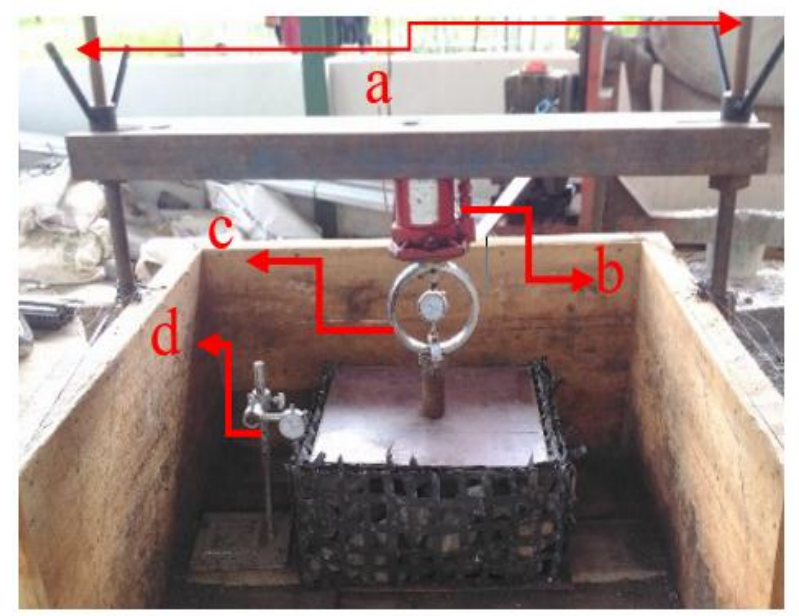

a. loading frame b. hydraulic jack c. load dial d. dial gauge

Figure 6. Loading Test Set Up.

\section{Results and Discussion}

In the loading test, the gabion wall models were loaded up to failure. The strength of the models was analyzed by stress-displacement curves from the loading test. The results of this experiment are presented in Figure 7.

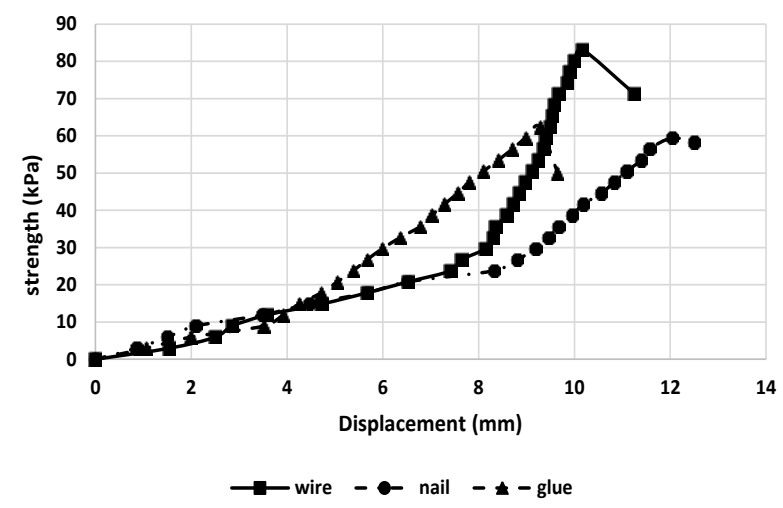

Figure 7. Correlation between Load and Displacement.

As can be seen in Figure 7, all connectors have a similar pattern in their load-displacement relation curves. When load was applied to the sample, the gabion wall almost reaches failure, though the box postponed it until the real failure. Based on Figure 7, the strength capacities of the gabion wall stripe models are $83.197,59.426$, and $62.397 \mathrm{kPa}$ for the wire, nail, and glue connectors, respectively. Hence, it can be inferred that the wire connector is the strongest of the three connectors.

Stiffness, the stress-strain ratio in a linear condition, is the other parameter to measure strength capacity. To achieve this, a correlation between stress and strain that were taken from the loading test are presented. The stress-strain correlation for each variation of connector is shown in Figure 8.

Figure 8 shows that each model has two values of stiffness with respect to the stress-strain correlation 
pattern. The first stiffness value is obtained by the first gradient when the failure condition is almost reached. The second stiffness value is determined by the second gradient. Based on Figure 8, the first stiffness values of all connectors are nearly the same. This condition indicates that loads were endured by the rock itself. The woven waste tires started to endure the load when the first condition is reached. In the second condition, the wire connector produces the highest value of stiffness, as well as the strength. The details of stiffness value for the gabion wall models are presented in Figure 9.

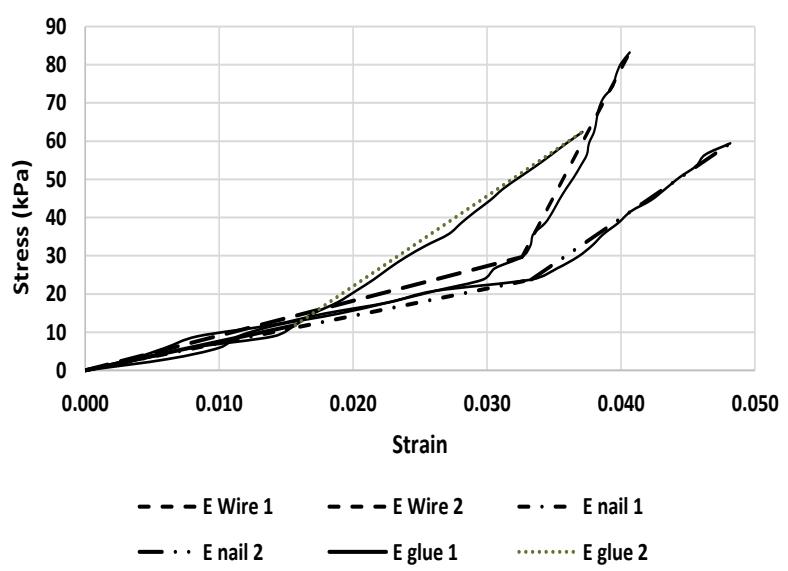

Figure 8. Correlation Between Stress and Strain for Each Connector Type

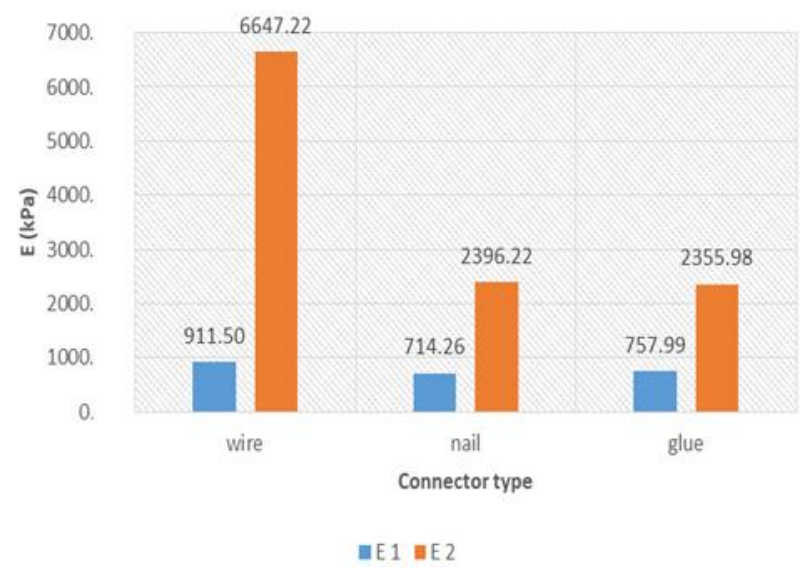

Figure 9. Elastic Modulus for Each Connector Type

\section{Conclusion}

Based on a laboratory model test, the wire is the most suitable connector for woven waste tire-based gabion walls according to both strength capacity and stiffness value. Compared with two other connectors, the wire results in an approximately three-fold increase in stiffness. The result of this study shows that woven waste tire stripes-based gabion wall with wire connector is applicable to prevent riverbank landslides.

\section{Acknowledgments}

The authors give thanks to the minister of research technology and higher education for supporting this study through an Applied Research Grant in 2019 and to the Soil Mechanic Laboratory of Jenderal Soedirman University for providing the soil mechanic testing machine.

\section{References}

1. BNPB, Bencana Menurut Jenisnya Di Indonesia Tahun 2009 S/D 2019, Jakarta, 2019.

2. Toprak, B., Sevim, O., and Kalkan, I., Gabion Walls and Their Use, International Journal Advance Mechanical Civil Engineering, 3(4), 2016, pp. 2394-2827,

3. Dekoruma, Kupas Tuntas Bronjong, dari Penahan Longsor Hingga Bagian Arsitektur Rumah, 2019. [Online]. Available: https://www.dekoruma. com/artikel/62125/apa-itu-bronjong. [Accessed: 25-Apr-2019].

4. Singh, J. and Singh, J., Application of Waste Tyre Rubber in Construction Industry, International Journal Civil, Structure Environment Infrastructure Engineering Research Dev., 5(3), pp. 57-64, 2015.

5. Bjegović, D., Baričević, A., and Serdar, M., Durability properties of concrete with recycled waste tyres, in International Conference on Durability of Building Materials and Composites, 2011, pp. 1659-1667.

6. Abas, F.O., Ghafoor, E.A.A., Abass, M.U., and Kamil, T., Re-Use of Waste Tires Rubber As Fine Aggregate Replacement, International Journal Engineering Science Research Technology, 4(3), 2015, pp. 110-120.

7. Nastain and Maryoto, A., Pemanfaatan Pemotongan Ban Bekas untuk Campuran Beton Serat Perkerasan Kaku, Dinamika Rekayasa, 6(1), 2010, pp. 14-18.

8. Apriyono, A., Sumiyanto, and Gusmawan, D.D., Application of Woven Tires Waste as soft Clay Subgrade Reinforcement for Preventing Highway Structural Failure, in AIP Conference Proceedings, 2017, 1818.

9. Cecich, V., Gonzales, L., Hoisaeter, A., and Williams, J., Use of Shredded Tires As Lightweight Backfill Material for Retaining Structures, Waste Management Reseach, 14, 1996, pp. 433-451.

10. Nakajima, Y., and Matsuyuki, M., Utilization of Waste Tires as Fuel for Cement Production, Resources, Conservation and Recycling, 4(3), 1981, pp. 145-151.

11. Apriyono, A., Sumiyanto, Yanto, and Bogie, A.H., Application of woven waste tires gabion wall as slope reinforcement for preventing landslide in Laboratory, MATEC Web of Conferences 195, 03007, 2018, pp. 1-8. 